\title{
Pengembangan Model Permainan untuk Pembelajaran Teknik Dasar Bola Basket di SMP
}

\author{
Dedi Wahyu Prasetyo $^{1}$ *, Yustinus Sukarmin ${ }^{2}$ \\ ${ }^{12}$ Program Studi Ilmu Keolahragaan, Program Pascasarjana, Universitas Negeri Yogyakarta. Jalan \\ Colombo No. 1, Karangmalang, Yogyakarta 55281, Indonesia \\ * Korespondensi Penulis. Email: w.dedi20@yahoo.com \\ Received: 26 January 2017; Revised:17 April 2017; Accepted: 19 April 2017
}

\begin{abstract}
Abstrak
Tujuan penelitian ini adalah menghasilkan model permainan untuk pembelajaran teknik dasar bola basket di sekolah menengah pertama. Pendekatan yang dilakukan dalam penelitian ini adalah penelitian dan pengembangan. Pengembangan produk model permainan untuk pembelajaran teknik dasar bola basket di sekolah menengah pertama dilakukan dalam tujuh tahapan, yaitu: (1) pengumpulan hasil riset dan informasi, (2) analisis terhadap produk yang akan dikembangkan, (3) mengembangkan produk awal, (4) validasi ahli, (5) uji coba skala kecil dan revisi, (6) uji coba skala besar dan revisi, dan (7) pembuatan produk final. Subjek penelitian ini adalah anak sekolah menengah pertama. Uji coba skala kecil dilakukan terhadap 25 siswa SMP N 4 Pandak. Uji coba skala besar dilakukan terhadap 56 siswa SMP N 1 Pandak dan SMP N 3 Pandak. Instrumen pengumpulan data yang digunakan yaitu: (1) pedoman wawancara, dan (2) pedoman observasi pembelajaran. Teknik analisis data yang dilakukan yaitu analisis deskriptif kuantitatif dan analisis deskriptif kualitatif. Hasil penelitian ini berupa model permainan untuk pembelajaran teknik dasar bola basket di sekolah menengah pertama yang berisikan sembilan permainan, yaitu: (1) Lempar Nama, (2) Lempar Target, (3) Lempar Gerak, (4) Fun Dribbling, (5) Target Dribbling, (6) Kejar Mengejar, (7) Tembak Tongkat, (8) Rintang Tali, dan (9) Happy Game. Dari hasil penilaian para ahli dan guru, dapat ditarik kesimpulan bahwa model permainan yang disusun sangat sesuai dengan karakteristik serta pertumbuhan dan perkembangan teknik dasar pada anak sekolah menengah pertama.
\end{abstract}

Kata Kunci: permainan, teknik dasar, bola basket

\section{Developing Game Models for Basketball Basic Technique Learning in Junior High School}

\begin{abstract}
The research aims to create game models for basketball basic learning technique in Junior High School. The research approach used is Research and Development. The development of the game model products for basketball basic technique learning process in Junior High School was devided into seven steps: (1) collecting research result and information, (2) products development analysis, (3) primary product development, (4) expert validation, (5) small-scale testing and revision, (6) large-scale testing and revision, and (7) creating final product. The research subjects are Junior High School students. The smallscale testing involved 25 students of SMPN 4 Pandak. The main field test involved 56 students of SMPN 1 Pandak and SMPN 3 Pandak. The data collecting instruments are: (1) interview and (2) learning observation. The data analysis techniques employed are descriptive quantitative and descriptive qualitative techniques. The research results are game models for basketball basic learning technique in Junior High School. There are nine game models: (1) Name Throw, (2) Target Throw, (3) Moving Throw, (4) Fun Dribbling, (5) Target Dribbling, (6) Tag Game, (7) Stick Shooting, (8) Rope Barricad, and (9) Happy Game. From the judgement result of the experts and teachers it can be concluded that the game models are very suitable for Junior High School students characteristics and also their growth and development on the basic techniques.
\end{abstract}

Keywords: games, basic technique, basketball

How to Cite: Prasetyo, D., \& Sukarmin, Y. (2017). Pengembangan model permainan untuk pembelajaran teknik dasar bola basket di SMP. Jurnal Keolahragaan, 5(1), 12-23. doi:http://dx.doi.org/10.21831/jk.v5i1.12758

Permalink/DOI: http://dx.doi.org/10.21831/jk.v5i1.12758 


\section{PENDAHULUAN}

Pendidikan jasmani adalah suatu proses pembelajaran yang didesain untuk meningkatkan kebugaran, mengembangkan keterampilan motorik, pengetahuan hidup aktif, dan sikap sportif melalui kegiatan jasmani. Kegiatan jasmani akan berjalan dengan baik jika mempraktikkan berbagai teknik dasar permainan dan olahraga, serta nilai-nilai yang terkandung di dalamnya.

Berdasarkan ruang lingkup pendidikan jasmani, siswa memiliki apresiasi terhadap perilaku bermain dan berolahraga yang termanifestasikan ke dalam nilai-nilai, seperti kerja sama, menghargai teman dan lawan, jujur, adil, dan terbuka. Siswa memiliki konsep dan keterampilan berpikir dalam berbagai permainan dan olahraga, dan siswa mampu melakukan berbagai macam bentuk aktivitas permainan dan berbagai cabang olahraga. Salah satu cabang olahraga yang populer adalah bola basket, yang penggemarnya berasal dari segala usia terutama pada kalangan pelajar dan mahasiswa. Mereka bisa merasakan bahwa bola basket adalah olahraga yang menyenangkan, kompetitif, mendidik, menghibur, dan menyehatkan. Sejalan dengan pertumbuhan dan perkembangan cabang olahraga bola basket, upaya pencapaian prestasi yang maksimal harus selalu diusahakan. Pencapaian prestasi yang maksimal tidak semudah yang dibayangkan, tetapi harus ada persiapan yang matang, usaha keras ditunjang dengan faktor-faktor yang mendukung.

Faktor-faktor yang mendukung untuk bermain bola basket ada dua, yaitu faktor internal dan faktor eksternal. Faktor internal antara lain teknik, psikologis, motivasi, dan fisik, sedangkan faktor eksternal antara lain fasilitas, motivasi, dan lingkungan.

Olahraga di Indonesia sudah banyak mengalami perubahan ke arah yang lebih baik dalam cara melakukannya bagi masyarakat umum, dari kalangan atas, dan bawah. Olahraga sudah menjadi hal yang penting dalam kehidupan sehari-hari, walaupun dengan intensitas yang masih rendah. Dalam dunia pendidikan ataupun nonpendidikan olahraga juga semakin mendapatkan perhatian berupa penambahan jam pelajaran pendidikan jasmani olaharaga dan kesehatan (penjasorkes), dan sudah disediakan buku panduan baik untuk melakukan olahraga maupun untuk mengukur kemampuan berolahraga.
Perkembangan olahraga yang semakin maju dan modern perlu perubahan dalam hal cara melakukan kegiatannya, khususnya bagi masyarakat yang belum mengerti bahwa berolahraga merupakan kegiatan yang perlu dilakukan.

Bola basket adalah olahraga beregu yang mengandalkan teknik, fisik, psikologis, kecepatan, dan ketahanan tubuh. Hany Ahmed (El-Aal, 2012, p. 428) menyatakan, Basketball game is one of the sportactivities that has a positive effect on learner in physical, mental and social sides as a result of that it acquires a wide attention locally and globally, it concerns with the variety of concepts and basic skills as a fundamental requirements to learn.

Teknik digunakan untuk melakukan gerakan dengan efektif dan efisien di dalam suatu kegiatan bermain bola basket. Kecepatan digunakan untuk melakukan suatu teknik dengan waktu yang relatif singkat digunakan saat melakukan serangan balik dari bertahan ke menyerang atau sebaliknya. Adapun ketahanan tubuh digunakan untuk melakukan teknik dengan konsisten sepanjang pertandingan. Pada permainan bola basket, menurut Ahmadi (2008, p. 13) untuk mendapatkan suatu tim bola basket yang handal, ada tiga faktor utama yang harus dipenuhi, yaitu penguasaan teknik dasar (fundamentals), ketahanan fisik (physical condition), dan kerja sama.

Keterampilan perseorangan seperti passing, dribbling, dan shooting, serta kerja sama tim untuk menyerang atau bertahan, adalah prasyarat agar berhasil dalam memainkan olahraga ini. Passing adalah salah satu kunci keberhasilan serangan sebuah tim dan sebuah unsur penentuan tembakan-tembakan yang berpeluang besar mencetak angka (Oliver, 2004, p. 35). Dribbling adalah mencari peluang serangan, menerobos pertahanan lawan, ataupun memperlambat tempo permainan (Ahmadi, 2007, p. 17). Shooting adalah usaha memasukkan bola ke keranjang (Ahmadi, 2007, p. 18).

Tim yang tersusun dari pemain-pemain yang memiliki teknik block, rebound, dan screen tidak menjamin kemenangan dalam pertandingan jika tidak didukung oleh tingkat keberhasilan keterampilan bermain bola basket yang baik.

Dalam permaianan bola basket selain taktik dan strategi yang baik juga perlu ada teknik dalam bermain supaya menghasilkan kemenangan. Banyak hal yang dilakukan oleh seorang pelatih untuk memberikan taktik dan strategi 
dalam setiap pertandingan tetapi teknik yang dimiliki seorang atlet belum maksimal atau tidak baik. Teknik yang dilakukan dalam pertandingan tentunya juga dilakukan dalam setiap latihan supaya para atlet paham dan bisa melaksanakan berbagai teknik yang telah dilakukan.

Dalam pertandingan, pelatih mempunyai berbagai pola yang dilakukan, hal ini kadangkadang menyebabkan atlet akan melakukan taktik dan strategi yang banyak, maka dari itu harus didukung dengan teknik yang baik supaya bisa berjalan baik. Dalam pelaksanaan pertandingan, pola yang dilakukan sering tidak dapat berjalan lancar karena berbagai macam faktor seperti tingkat keterampilan setiap individu, pola yang diterapkan oleh tim lawan, kondisi pemain, konsentrasi pemain, serta kerja sama tim.

Olahraga bola basket juga diberikan pada bidang pendidikan khususnya pada pelajaran penjasorkes di sekolah. Hal inilah sebenarnya yang merupakan salah satu faktor yang memengaruhi para pelajar mengenal bola basket khususnya pada kegiatan intrakurikuler bola basket yang diadakan di sekolah akan menarik minat para pelajar yang menggemarinya. Teknik dasar perseorangan seperti passing, dribbling, dan shooting adalah prasyarat agar berhasil dalam memainkan olahraga ini.

Teknik dasar dapat diartikan sebagai indikator dari tingkat kemahiran atau penguasaan suatu hal yang memerlukan gerak tubuh. Siswa sekolah menengah pertama (SMP) yang baru mengenal cara bermain bola basket, sering mengalami kesulitan dalam melakukan gerakangerakan dasar bola basket. Untuk mempelajari teknik dasar seperti dribbling, shooting, dan passing, dalam permainan bola basket hendaknya dilaksanakan dengan sebaik-baiknya supaya cepat menguasai. Pembelajaran yang baik akan memudahkan siswa untuk cepat memahami materi dribbling, shooting, dan passing, sehingga guru harus pintar membuat pembelajaran yang mudah dipahami siswa. Oleh karena itu, metode atau prosedur untuk pencapaian tujuan tersebut haruslah dipikirkan secara matang agar dapat diperoleh hasil yang optimal.

Pengunaan metode yang tepat merupakan tuntutan yang mutlak untuk pencapaian suatu tujuan latihan, yaitu untuk peningkatan teknik dasar. Makin cocok metode yang dipilih dalam proses pembelajaran, makin efektif pula tujuan pembelajaran yang dilaksanakan. Permainan bola basket sendiri merupakan jenis permainan yang menggunakan bola besar, dimainkan oleh dua regu yang masing-masing terdiri atas lima orang pemain. Menurut Muhajir (2016, p. 11) bola basket adalah suatu permainan yang dimainkan oleh dua regu yang masing-masing terdiri atas lima orang pemain. Pembelajaran dasar bermain basket biasanya terdapat dalam kurikulum, yaitu melalui pembelajaran penjasorkes sebagai salah satu usaha untuk meningkatkan teknik dasar anak bermain bola basket.

Melalui kegiatan pembelajaran bola basket diharapkan siswa dapat memperdalam dan memperluas pengetahuan yang berkaitan dengan mata pelajaran penjasorkes serta dapat meningkatkan bakat, minat, keterampilan, dan sebagai ajang mencari tahu atau prestasi.

Metode dalam berbagai variasi pembelajaran bola basket tersebut sangat perlu digunakan dalam proses kegiatan belajar mengajar dengan berbagai pertimbangan fisiologis maupun psikologis. Berdasarkan observasi yang peneliti lakukan di berbagai sekolah serta pada saat menjadi pemain, guru, dan pelatih banyak siswa yang terkadang mengalami kejenuhan dalam pembelajaran bola basket.

Pembelajaran yang dilakukan oleh guru dan pelatih memerlukan model permainan yang bervariasi dan menarik, yang mendukung dalam meningkatkan teknik dasar siswa dalam bermain bola basket. Teknik dasar bola basket yang terdiri atas passing, dribbling, dan shooting merupakan teknik yang sering dilakukan siswa dalam melakukan permainan basket dalam sebuah pertandingan. Melalui sebuah model permainan, semestinya akan dipermudah proses penyampaian materi kepada siswa.

Pengembangan model permainan dalam pembelajaran bola basket untuk anak SMP dapat mendatangkan beberapa keuntungan sekaligus, karena: (1) anak dapat bermain sambil mengembangkan keterampilan jasmani, (2) anak mendapat materi aktivitas jasmani sambil bermain, dan (3) menambah wawasan guru mengenai variasi pembelajaran bola basket. Pengembangan model permainan yang bervariasi akan membantu siswa dalam memahami dan memudahkan siswa dalam mempelajari teknik dasar bermain bola basket. Pembuatan model permainan dalam pembelajaran teknik dasar pada anak SMP harus memperhatikan gerak dasar aktivitas jasmaninya, hal ini akan lebih memudahkan anak dalam mempelajari teknik dasar bola basket. Tahapan pertumbuhan dan perkembangan merupakan aspek yang sangat penting untuk dipertimbangkan dalam perencanaan proses pembelajaran yang akan diikutinya. 
Kemampuan teknik dasar bola basket yang perlu dikembangkan pada anak SMP adalah kemampuan teknik fundamental. Pengembangan model permainan dalam pembelajaran perlu ada media yang dapat dimanfaatkan dalam pembelajaran untuk menghilangkan kesan kurang menarik karena keterbatasan alat dan upaya untuk memberikan modifikasi sehingga minat siswa lebih terlihat. Pada umumya guru penjasorkes menyampaikan materi berupa teori dengan ceramah, padahal seharusnya lebih banyak aktivitas fisik yang membuat siswa aktif bergerak. Penggunaan berbagai aktivitas fisik dan bermain diharapkan siswa dapat memahami materi pembelajaran layaknya belajar di dalam kelas.

Pemanfaatan berbagai model permainan dalam pembelajaran yang variatif adalah memanfaatkan model permainan yang dibuat menyerupai bentuk sesungguhnya sebagai alat bantu siswa agar lebih memahami materi. Model permainan bahan ajar yang disajikan melalui aktivitas fisik dengan model yang telah dimodifikasi menjadikan kegiatan proses belajar mengajar menjadi lebih menarik, menantang, serta memudahkan bagi siswa. Model permainan berupa permainan shooting, dribbling, dan passing perlu dibuat dan dikembangan supaya bisa semakin bervariasi yang dapat dilakukan oleh guru.

Penggunaan model permainan ini bermanfaat bagi siswa karena memperhatikan perbedaan karakteristik, minat, dan bakat siswa. Selain itu pengunaan model permainan ini merupakan suatu usaha yang sistematik dan terencana sehingga dapat mengatasi kelemahankelemahan yang ada pada pembelajaran bola basket. Pembelajaran yang sistematik dapat membentuk siswa belajar dengan efektif dan efisien.

Pengembangan model permainan memberikan kesempatan kepada siswa untuk belajar, bukan hanya dari satu sumber yakni guru, melainkan memberikan kesempatan kepada subjek belajar untuk megembangkan kognitif dengan lebih baik, kreatif, dan inovatif. Agar pembelajaran menarik hendaknya bisa dilakukan dengan rangkaian kegiatan yang melibatkan kemampuan shooting, dribbling, dan passing. Pemanfaatan model permainan bola basket yang meliputi model permainan shooting, dribbling, dan passing diharapkan dapat membantu guru untuk mendesain kegiatan pembelajarannya yang bervariasi.
Pengembangan model permainan yang bervariasi antara lain dapat digunakan untuk mempermudah penguasaan teknik dasar, meningkatkan teknik dasar, dan menghilangkan kejenuhan saat melakukan permainan bola basket. Diketahui selama ini kebanyakan guru penjasorkes sangat minim dalam memanfaatkan alat-alat pembelajaran dan kurang variatif dalam pembelajaran. Oleh sebab itu, model permainan dalam pembelajaran yang dirancang dengan sedemikian rupa ini diharapkan dapat membantu tugas guru penjasorkes dalam melaksanakan tugas.

Tujuan penelitian ini adalah menghasilkan model permainan untuk pembelajaran teknik dasar bola basket di sekolah menengah pertama.

\section{METODE}

Penelitian ini menggunakan pendekatan penelitian dan pengembangan, sesuai dengan pendapat Gall, Gall, \& Borg (2007, p. 772) bahwa penelitian dan pengembangan adalah suatu proses yang digunakan untuk mengembangkan atau memvalidasi produk-produk yang digunakan dalam pendidikan dan pembelajaran. Dunia pendidikan membutuhkan metode penelitian dan pengembangan untuk meningkatkan kualitas pendidikan.

Prosedur pengembangan merupakan langkah-langkah yang harus diikuti sebelum menghasilkan sebuah produk. Langkah-langkah penelitian dan pengembangan menurut Gall et al. (2007, p. 775) meliputi 10 langkah yang harus dilaksanakan, yaitu: (1) pengumpulan informasi, (2) perencanaan, (3) pengembangkan produk awal, (4) uji coba awal, (5) revisi untuk menyusun produk utama, (6) uji coba lapangan utama, (7) revisi untuk menyusun produk operasional, (8) uji coba produk operasional, (9) revisi produk final, dan (10) diseminasi dan implementasi produk hasil pengembangan. Dari hasil produk diseminasi tersebut nantinya dapat diimplementasikan secara luas oleh pendidik, para pengajar SMP maupun penggiat pendidikan sesuai dengan usia dan karakter siswa. Dwiyogo (2004, p. 6) menyatakan bahwa setiap peneliti dapat memilih dan menentukan langkah yang paling tepat bagi penelitian pengembangan yang dilakukannya berdasarkan kondisi dan kendala yang dihadapi. Berdasarkan pendapat tersebut dalam penelitian ini dalam prosedur pengembanganya dilakukan penyederhanaan sesuai dengan kendala dan kondisi dalam penelitian.

Langkah-langkah tersebut diadaptasi menjadi tujuh rancangan prosedur penelitian 
pengembangan, yaitu pengumpulan informasi, analisis produk yang dikembangkan, pengembangan produk awal, validasi ahli, uji coba skala kecil, uji coba skala besar, pembuatan produk akhir. Hal ini dikarenakan penelitian pengembangan adalah penelitian yang berorientasi pada produk, maka untuk langkah penelitian ini cukup dengan tujuh langkah. Tujuh langkah pelaksanaan penelitian pengembangan selanjutnya bisa dikembangkan dalam penelitian eksperimen.

\section{Pengumpulan Penelitian dan Informasi di Lapangan}

Peneliti melakukan kajian awal mengenai karakteristik pertumbuhan dan perkembangan pada anak SMP. Berdasarkan hal tersebut peneliti melakukan wawancara sekilas dengan salah satu guru penjasorkes dan siswa dengan hasil bahwa memang terdapat permasalahan di lapangan terkait pembelajaran bola basket.

Oleh karena itu, peneliti tertarik untuk melakukan penyelidikan lebih jauh. Proses selanjutnya, dilakukan pengumpulan informasi lebih lanjut dengan melakukan studi pendahuluan baik dengan cara studi pustaka maupun wawancara langsung dengan para guru dan siswa. Hal yang dilakukan dalam studi pustaka yaitu mengumpulkan bahan mengenai teoriteori, data, dan hasil penelitian yang terkait dengan penelitian ini.

\section{Melakukan Analisis terhadap Produk yang akan Dikembangkan}

Analisis yang dilakukan yaitu: (a) analisis aktivitas jasmani yang terkait dengan proses pembelajaran bola basket pada anak SMP, dan (b) analisis pembelajaran bola basket yang sesuai bagi anak SMP.

\section{Mengembangkan Produk Awal}

Dalam pembuatan produk awal perlu diperhatikan beberapa aspek, yaitu: (a) menganalisis tujuan dan karakteristik model permainan untuk pembelajaran bola basket pada anak SMP, (b) menganalisis karakteristik anak SMP, (c) mengkaji literatur tentang prinsip-prinsip pembelajaran bola basket atau cara mengembangkan pembelajaran bola basket pada anak SMP, (d) menetapkan prinsip-prinsip untuk model permainan untuk pembelajaran bola basket untuk anak SMP, (e) menetapkan tujuan, isi, dan strategi pengelolaan pembelajaran, (f) mengembangkan prosedur pengukuran hasil pembelajaran, dan (g) menyusun produk awal bentuk model permainan untuk pembelajaran bola basket untuk anak SMP.

\section{Validasi Ahli}

Produk awal model permainan untuk pembelajaran bola basket untuk anak SMP adalah sebuah draf buku panduan praktis mengajar teknik dasar bermain bola basket. Sebelum diujicobakan dalam uji skala kecil perlu dilakukan validasi oleh para ahli dan praktisi yang sesuai dengan bidang penelitian ini. Untuk memvalidasi produk yang akan dihasilkan, peneliti melibatkan dua orang ahli yang berasal dari dosen sebagai ahli permainan bola basket (Budi Aryanto, M.Pd.) dan pembelajaran bola basket (Tri Ani Hastuti, M.Pd) serta satu orang guru penjasorkes sebagai praktisi.

\section{Uji Coba Skala Kecil dan Revisi}

Uji coba lapangan skala kecil dilakukan dan didokumentasikan dalam bentuk digital video disc (DVD), yang kemudian diobservasi oleh para ahli. Observasi dilakukan terhadap substansi permainan dalam pembelajaran, kesesuaian model permainan dalam pembelajaran, guru pelaksana uji coba, maupun draf produk buku panduan pembelajaran, dengan menggunakan pedoman observasi yang disusun oleh peneliti. Masukan yang diterima dari para pakar dan guru ditindaklanjuti dengan melakukan revisi produk.

\section{Uji Coba Skala Besar dan Revisi}

Proses yang dilakukan pada tahap uji coba lapangan skala besar serupa dengan proses yang dilakukan pada tahap uji coba skala kecil. Hal yang membedakan terletak pada jumlah subjek uji coba skala besar yang lebih banyak daripada uji coba skala kecil. Dalam hal ini, subjek uji coba yang sudah mengikuti uji coba skala kecil tidak turut serta dalam uji coba skala besar. Proses revisi produk dilakukan setelah mendapat masukan dari para ahli untuk menghasilkan produk final. Masukan dari guru penjasorkes tempat pelaksanaan uji coba skala besar juga dipertimbangkan sebagai bahan untuk merevisi produk.

\section{Pembuatan Produk Final}

Setelah melalui berbagai proses revisi, dilakukan penyusunan dan pembuatan produk akhir atau produk final berupa buku panduan permainan untuk pembelajaran teknik dasar bermain bola basket untuk SMP. Buku panduan yang dibuat untuk memudahkan guru atau 
pendidik untuk mengajarkan permainan bola basket, terutama mengenai teknik dasar yang meliputi shooting, passing, dan dribbling .

Pelaksanaan penelitian dilakukan pada tanggal 11 Februari-17 Maret 2015. Tempat penelitian di SMP Negeri 4 Pandak, SMP Negeri 3 Pandak, dan SMP Negeri 1 Pandak. Subjek uji coba merupakan sasaran pemakai produk, yaitu anak SMP yang berasal dari uji coba skala kecil yang dalam penelitian ini menggunakan siswa SMP Negeri 4 Pandak yang berjumlah 25 siswa. Di sisi lain, uji coba skala besar dalam penelitian ini menggunakan siswa SMP Negeri 3 Pandak yang berjumlah 28 siswa, dan SMP Negeri 1 Pandak yang berjumlah 28 siswa.

Data yang digunakan dalam penelitian ini berupa data kualitatif dan data kuantitatif. Jenis data kualitatif berasal dari: (a) hasil wawancara dengan guru penjasorkes, dan (b) data masukan ahli materi dan guru penjasorkes uji coba terhadap model permainan untuk pembelajaran. Data kuantitatif diperoleh dari hasil observasi pembelajaran yang berupa lembar penilaian terhadap model permainan.

Instrumen pengumpulan data dalam penelitian ini menggunakan pedoman observasi dan pedoman wawancara. Observasi dilakukan untuk mendapatkan atau menjaring informasi dari para ahli untuk memberikan masukan dan saran tentang produk yang akan dihasilkan, yaitu pelaksanaan proses pembelajaran teknik dasar bola basket pada anak SMP. Instrumen angket disusun untuk mengetahui kualitas produk yang dihasilkan.

Setelah dihasilkan produk akhir dilanjutkan uji keefektifan dengan menggunakan eksperimen yang dilakukan di SMP N 3 Pandak dengan jumlah siswa 28 siswa kelas 7 . Uji keefektifan produk dilakukan sebanyak 3 kali dengan rincian pertemuan 1 dilakukan 5 permainan, pertemuan 2 dilakukan 4 permaian, dan pertemuan 3 melakukan 9 permainan. Intrumen pada uji keefektifan adalah tes kecakapan bermain bola basket menggunakan Johnson Basket Ball Test. Tes ini meliputi: (1) menembakkan bola ke ring basket, (2) melemparkan bola ke arah sasaran, dan (3) menggiring bola. Pelaksanaan tes dilakukan sebanyak satu kali setiap testi. Hasil tes shooting dicatat sesuai bola yang masuk ke ring basket selama 30 detik, hasil passing dicatat sesuai dengan hasil lemparan sebanyak 10 kali kesempatan, dan hasil dribbling dicatat sesuai dengan jumlah gawang yang berhasil dilewati selama 30 detik.
Teknik analisis data yang dilakukan dalam penelitian ini yaitu analisis deskriptif kuantitatif dan analisis deskriptif kualitatif. Analisis deskriptif kuantitatif dilakukan untuk menganalisis data-data berikut: (1) data skala nilai hasil penilaian para ahli materi terhadap draf model permainan sebelum pelaksanaan uji coba di lapangan, dan (2) data hasil observasi para ahli terhadap model permainan. Sementara analisis deskriptif kualitatif dilakukan terhadap: (1) data hasil wawancara dengan guru penjasorkes saat studi pendahuluan, dan (2) data masukan terhadap model permainan baik sebelum uji coba maupun setelah uji coba di lapangan.

Model yang disusun dianggap layak diujicobakan dalam skala kecil dan besar apabila memenuhi syarat skor yang diraih mencapai standar minimal kelayakan. Ketentuan kelayakan dari sebuah model untuk bisa diujicobakan di lapangan dijelaskan dengan melakukan pengategorisasian 9 butir pernyataan pada lembar observasi tentang model permainan teknik dasar bola basket anak SMP menggunakan Skala Likert 5 pilihan jawaban. Skor paling tinggi adalah apabila memilih sangat sesuai, yaitu 5, dan skor paling rendah adalah apabila memilih jawaban sangat tidak sesuai, yaitu 1. Jadi skor tertinggi adalah 9 butir x $5=45$, dan skor terendah adalah 9 butir x $1=9$ (Mardapi 2012, p.163). Skor didapatkan dari pengisian instrumen berupa lembar observasi yang telah diberikan, dengan 5 skala penilaian 1, 2, 3, 4, 5 . Skala tersebut selanjutnya diterjemahkan ke dalam hasil pengukuran seperti pada Tabel 1.

Tabel 1. Tabulasi Skor Penilaian

\begin{tabular}{cccc}
\hline No. & $\begin{array}{c}\text { Skor } \\
\text { Penilaian }\end{array}$ & Pernyataan & $\begin{array}{c}\text { Skor } \\
\text { Maksimal }\end{array}$ \\
\hline 1. & 5 & 9 & 45 \\
2. & 4 & 9 & 45 \\
3. & 3 & 9 & 45 \\
4. & 2 & 9 & 45 \\
5. & 1 & 9 & 45 \\
\hline
\end{tabular}

Mardapi (2012, p. 163) menyatakan instrumen yang dibuat harus ditelaah oleh teman sejawat untuk mengetahui keterbacaan, substansi yang ditanyakan, dan bahasa yang digunakan. Hasil telah digunakan untuk memperbaiki instrumen, selanjutnya instrumen diujicobakan di lapangan. 
Tabel 2. Kategorisasi Model Permainan untuk Pembelajaran Teknik Dasar Bola Basket untuk Anak Sekolah Menengah Pertama

\begin{tabular}{cll}
\hline No. & Aspek Penilaian & \multicolumn{1}{c}{ Skor } \\
\hline 1. & $\begin{array}{l}\text { Sama atau lebih } \\
\text { besar dari 36 }\end{array}$ & $\begin{array}{l}\text { Sangat baik/sangat } \\
\text { efektif }\end{array}$ \\
2. & 27 sampai 35 & Baik/efektif \\
3. & 18 sampai 26 & $\begin{array}{l}\text { Cukup baik/cukup } \\
\text { efektif }\end{array}$ \\
4. & Kurang dari 17 & $\begin{array}{l}\text { Sangat tidak baik/sangat } \\
\text { tidak efektif }\end{array}$ \\
\hline
\end{tabular}

Keterangan: (1) skor batas bawah kategori sangat sesuai atau sangat efektif adalah: $0,80 \mathrm{x}$ $45=36$, dan batas atasnya adalah 36, (2) skor batas bawah pada kategori sesuai atau efektif adalah: $0,60 \times 45=27$, dan skor batas atasnya adalah 27, (3) skor batas bawah pada kategori cukup sesuai atau cukup efektif adalah: 0,40 x $45=18$, dan batas atasnya adalah 18 , dan (4) skor yang tergolong pada kategori sangat tidak sesuai atau sangat tidak efektif adalah: kurang dari 9.

Metode yang digunakan dalam uji keefektifan produk akhir ini adalah pre-experiment design. Lebih jelasnya adalah desain kelompok tunggal dengan pretest-posttest (One group pretest-posttest design). Kirk (2002, p. 26) menyatakan "the design enables a researcher to computte a contras between means in which the pretest and posttest means are measured with the same precision." Bell (2014, p. 2) menyatakan desain dalam pretest-posttest kelompok tunggal adalah:

\begin{tabular}{|l|l|l|}
\hline$O 1$ & $\mathbf{X}$ & $O 2$ \\
\hline
\end{tabular}

Keterangan:

$\mathrm{O} 1$ : Representatif dari pretest.

$\mathrm{X}$ : Representatif dari treatment.

$\mathrm{O} 2$ : Representatif dari posttest.

Adapun langkah-langkah yang ditempuh dalam eksperimen dari uji keefektifan produk akhir ini adalah sebagai berikut:

\section{Tahap Pretest}

Pada tahap pretest penilaian dilakukan kepada siswa yang menggunakan model permainan teknik dasar bola basket. Tes yang digunakan adalah tes Johnson Basketball Test yang meliputi passing, dribbling, dan shooting .

\section{Tahap Perlakuan/Treatment}

Pada tahap perlakuan atau treatment, dalam pembelajaran penjasorkes diberikan materi bola basket dengan menggunakan model permainan teknik dasar bola basket. Traeatment dilakukan pada jam penjasorkes sesuai dengan jadwal pelajaran. Tahapan model permainan diajarkan oleh guru dan siswa melakukannya sesuai dengan arahan buku petunjuk penggunaan model permainan. Pemberian perlakuan yang dilakukan guru terfokus pada jam pelajaran penjasorkes sesuai jadwal pelajaran sekolah. Pada saat pemberian perlakuan ada pengulangan model permainan dan itu tidak mengganggu pelajaran karena masih dalam materi permainan bola besar.

\section{Tahap Posttest}

Tahap posttest atau tes tahap akhir juga dilakukan dengan menggunakan Johnson Basketball Test yang meliputi passing, dribbling, dan shooting. Setelah diperoleh hasil pretest dan posttest berdasarkan hasil tes, langkah selanjutnya data dianalisis. Proses uji keefektifan model permainan teknik dasar bola basket untuk siswa SMP menggunakan uji beda selisih peningkatan rata-rata antara data hasil pertemuan tahap I (awal) dan pertemuan tahap II (akhir). Hal ini senada dengan pendapat Sugiyono (2006, p. 346) yang menyatakan, "uji beda dilakukan untuk menguji perubahan yang terjadi akibat suatu perlakuan peneliti terhadap subyek penelitian dan membandingkan skor awal dan skor akhir."

Adapun langkah-langkah dalam menganalisis hasil pembelajaran permainan melalui permainan teknik dasar bola basket adalah: (1) merekapitulasi data yang diperoleh dari Johnson Basketball Test yang meliputi passing, dribbling, dan shooting, (2) menghitung jumlah skor tiap-tiap siswa, dan (3) merata-rata hasil pretest dan posttest dilanjutkan dengan mencari selisih antara skor pretest dan skor posttest untuk mendapatkan nilai gain.

\section{HASIL DAN PEMBAHASAN}

Setelah melalui proses desain produk dihasilkan produk awal hingga produk akhir, tercipta model permainan untuk pembelajaran teknik dasar untuk anak SMP. Pada kegiatan pembelajaran teknik dasar ini dilakukan dengan bentuk-bentuk permainan. Model permainan inilah sebagai pembelajaran inti dari kegiatan belajar teknik dasar bola basket untuk anak SMP.

Menurut Saryono (2011, p. 51) modifikasi permainan dalam penjas dan olahraga memiliki karakterlistik sebagai berikut: (1) sesuai dengan kemampuan anak (umur, kesegaran jasmani, status kesehatan, tingkat keterampilan, dan 
pengalaman sebelumnya), (2) aman dimainkan, (3) memiliki beberapa aspek alternatif seperti ukuran berat dan bentuk peralatan, lapangan permainan, waktu bermain atau panjangnya permainan, peraturan, jumlah pemain, rotasi atau posisi pemain, (4) mengembangkan pemain dan keterampilan olahraga yang relevan yang dapat dijadikan dasar pembinaan selanjutnya. Keterampilan bermain bola basket akan tercapai apabila menguasai teknik gerakan yang efektif dan efisien. Chroni, Perkos, \& Theodorakis (2007, p. 19) menyatakan, Adolescent athletes are akin to their adult counterparts to learn and develop sport skills through practicing, and eventually they are asked to apply the acquired skills in game situations.

Melalui pengembangan model permainan ini, pembelajaran yang dilakukan dapat digunakan dalam pembelajaran teknik dasar bola basket yang efektif dan efisien.

Hasil penilaian dalam uji coba skala besar dapat diketahui bahwa model yang telah direvisi dari hasil uji coba skala kecil semakin menunjukkan kesesuaian dengan harapan, yaitu kesepakatan antarpakar dan guru penjasorkes serta ketetapan dan ketepatan hasil observasi terhadap model permainan untuk pembelajaran teknik dasar bola basket di SMP yang sangat sesuai. Hal ini dapat dilihat dari rata-rata skor penilaian observasi dan persentase kesesuaian model permainan. Hasil mengenai produk akhir dapat dilihat di Tabel 3.
Pengembangan model permainan untuk pembelajaran teknik dasar bola basket di SMP dideskripsikan dari pembuatan model yang dilakukan. Secara keseluruhan model yang dibuat dalam kategori sangat efektif berjumlah 7 dan yang efektif berjumlah 2. Untuk lebih jelasnya, pembahasan tiap-tiap model permainan, sebagai berikut:

\section{Permainan Lempar Nama}

Model permainan lempar nama untuk pembelajaran teknik dasar bola basket menunjukkan kategori sangat baik dengan ratarata 42,5 dan persentase $94,4 \%$. Hal-hal yang menyebabkan model permainan lempar nama dalam kategori sangat baik akan dijelaskan sebagai berikut: (a) permainan mengembangkan kemampuan siswa dalam mengoper bola dan pada saat melakukan permainan lempar nama siswa diharuskan berpikir, (b) siswa terlihat senang dan aktif ketika melakukan permainan lempar nama, (c) permainan lempar nama membekali siswa untuk memiliki kemampuan mengoper bola pada saat bermain bola basket dan sudah sesuai dengan karakteristik siswa, (d) permainan lempar nama berorientasi pada kebutuhan siswa dan dapat mengeksplorasi kegiatan belajar teknik dasar mengoper, (e) permainan mengembangkan kemampuan siswa dalam bekerja sama dan memotivasi siswa dalam berinteraksi dengan siswa yang lain, (f) dan permainan mendorong siswa untuk memecahkan masalah dan mendorong siswa dalam mematuhi peraturan.

Tabel 3. Data Hasil Uji Coba Produk Akhir

\begin{tabular}{clccccc}
\hline No. & Nama Kegiatan & A1 & A2 & G1 & G2 & Rata-Rata \\
\hline 1. & Lempar Nama & 43 & 43 & 42 & 42 & 42.5 \\
2. & Lempar Target & 44 & 44 & 43 & 43 & 43.5 \\
3. & Lempar Gerak & 43 & 44 & 42 & 44 & 43.2 \\
4. & Fun Dribbling & 44 & 43 & 41 & 41 & 42.2 \\
5. & Target Dribbling & 43 & 43 & 41 & 42 & 42.2 \\
6. & Kejar Mengejar & 36 & 36 & 35 & 35 & 35.5 \\
7. & Tembak Tongkat & 36 & 35 & 35 & 35 & 35.2 \\
8. & Rintang Tali & 44 & 44 & 41 & 43 & 43 \\
9. & Happy Game & 45 & 45 & 43 & 45 & 44.5 \\
Jumlah skor & & 378 & 377 & 366 & 370 & 372 \\
Rata-rata & & 42 & 41,8 & 40,6 & 41,1 & 41,3 \\
Persentase & & $93,3 \%$ & $92,2 \%$ & $90,2 \%$ & $91,3 \%$ & $91,3 \%$ \\
\hline
\end{tabular}




\section{Lempar Target}

Permainan lempar target untuk pembelajaran teknik dasar bola basket menunjukkan kategori sangat baik dengan rata-rata 43,5 dan persentase 96,6 \%. Hal-hal yang menyebabkan model permainan lempar target dalam kategori sangat baik akan dijelaskan sebagai berikut: (a) mengembangkan kemampuan siswa dalam mengoper bola dan pada saat melakukan permainan lempar target siswa diharuskan berpikir, (b) siswa terlihat senang dan aktif ketika melakukan permainan lempar target, (c) permainan lempar target membekali siswa untuk memiliki kemampuan mengoper bola pada saat bermain bola basket dan sudah sesuai dengan karakteristik siswa, (d) permainan lempar target berorientasi pada kebutuhan siswa dan dapat mengeksplorasi kegiatan belajar teknik dasar mengoper, (e) permainan mengembangkan kemampuan siswa dalam bekerja sama dan memotivasi siswa dalam berinteraksi dengan siswa yang lain, dan (f) permainan mendorong siswa untuk memecahkan masalah dan mendorong siswa dalam mematuhi peraturan.

\section{Permainan Lempar Gerak}

Model permainan lempar gerak untuk pembelajaran teknik dasar bola basket menunjukkan kategori sangat baik dengan rata-rata 43,2 dan persentase $96 \%$. Hal-hal yang menyebabkan model permainan lempar gerak dalam kategori sangat baik akan dijelaskan sebagai berikut: (a) mengembangkan kemampuan siswa dalam mengoper bola dan pada saat melakukan permainan lempar gerak siswa diharuskan berpikir, (b) siswa terlihat senang dan aktif ketika melakukan permainan lempar gerak, (c) permainan lempar gerak membekali siswa untuk memiliki kemampuan mengoper bola pada saat bermain bola basket dan sudah sesuai dengan karakteristik siswa, (d) permainan lempar gerak berorientasi pada kebutuhan siswa dan dapat mengeksplorasi kegiatan belajar teknik dasar mengoper, (e) permainan mengembangkan kemampuan siswa dalam bekerja sama dan memotivasi siswa dalam berinteraksi dengan siswa yang lain, dan (d) permainan mendorong siswa untuk memecahkan masalah dan mendorong siswa dalam mematuhi peraturan.

\section{Fun Dribbling}

Model permainan fun dribbling untuk pembelajaran teknik dasar bola basket menunjukkan kategori sangat baik dengan rata-rata
42,2 dan persentase 93,7 \%. Hal-hal yang menyebabkan model permainan fun dribbling dalam kategori sangat baik akan dijelaskan sebagai berikut: (a) mengembangkan kemampuan siswa dalam menggiring dan pada saat melakukan permainan fun dribbling siswa diharuskan berpikir, (b) siswa terlihat senang dan aktif ketika melakukan permainan fun dribbling, (c) permainan fun dribbling membekali siswa untuk memiliki kemampuan menggiring pada saat bermain bola basket dan sudah sesuai dengan karakteristik siswa, dan (d) permainan fun dribbling berorientasi pada kebutuhan siswa dan dapat mengeksplorasi kegiatan belajar teknik dasar menggiring.

\section{Target Dribbling}

Model permainan target dribbling untuk pembelajaran teknik dasar bola basket menunjukkan kategori sangat baik dengan rata-rata 42,2 dan persentase 93,7 \%. Hal-hal yang menyebabkan model permainan target dribbling dalam kategori sangat baik akan dijelaskan sebagai berikut: (a) mengembangkan kemampuan siswa dalam menggiring dan pada saat melakukan permainan target dribbling siswa diharuskan berpikir, (b) siswa terlihat senang dan aktif ketika melakukan permainan target dribbling, (c) permainan target dribbling membekali siswa untuk memiliki kemampuan menggiring pada saat bermain bola basket dan sudah sesuai dengan karakteristik siswa, (d) permainan target dribbling berorientasi pada kebutuhan siswa dan dapat mengeksplorasi kegiatan belajar teknik dasar menggiring, (d) permainan mengembangkan kemampuan siswa dalam bekerja sama dan memotivasi siswa dalam berinteraksi dengan siswa yang lain, dan (e) permainan mendorong siswa untuk memecahkan masalah dan mendorong siswa dalam mematuhi peraturan.

\section{Kejar Mengejar}

Model permainan kejar mengejar untuk pembelajaran teknik dasar bola basket menunjukkan kategori sangat baik dengan ratarata 35,5 dan persentase $78,8 \%$. Hal-hal yang menyebabkan model permainan kejar mengejar dalam kategori baik akan dijelaskan sebagai berikut: (a) mengembangkan kemampuan siswa dalam menggiring dan pada saat melakukan permainan kejar mengejar siswa diharuskan berpikir, (b) permainan kejar mengejar membekali siswa untuk memiliki kemampuan menggiring pada saat bermain bola basket dan 
sudah sesuai dengan karakteristik siswa, (c) permainan kejar mengejar berorientasi pada kebutuhan siswa dan dapat mengeksplorasi kegiatan belajar teknik dasar menggiring, dan (d) permainan mendorong siswa untuk memecahkan masalah dan mendorong siswa dalam mematuhi peraturan.

\section{Tembak Tongkat}

Model permainan tembak tongkat untuk pembelajaran teknik dasar bola basket menunjukkan kategori sangat baik dengan rata-rata 35,5 dan persentase $78,8 \%$. Hal-hal yang menyebabkan model permainan tembak tongkat dalam kategori baik akan dijelaskan sebagai berikut: (a) mengembangkan kemampuan siswa dalam menembak dan pada saat melakukan permainan tembak tongkat siswa diharuskan berpikir, (b) permainan tembak tongkat membekali siswa untuk memiliki kemampuan menembak pada saat bermain bola basket dan sudah sesuai dengan karakteristik siswa, (c) permainan tembak tongkat berorientasi pada kebutuhan siswa dan dapat mengeksplorasi kegiatan belajar teknik dasar menembak, dan (d) permainan mengembangkan kemampuan siswa dalam bekerja sama dan memotivasi siswa dalam berinteraksi dengan siswa yang lain.

\section{Rintang Tali}

Model permainan rintang tali untuk pembelajaran teknik dasar bola basket menunjukkan kategori sangat baik dengan rata-rata 43 dan persentase $95,5 \%$. Hal-hal yang menyebabkan model permainan rintang tali dalam kategori sangat baik akan dijelaskan sebagai berikut: (a) mengembangkan kemampuan siswa dalam menembak dan pada saat melakukan permainan rintang tali siswa diharuskan berpikir, (b) permainan rintang tali membekali siswa untuk memiliki kemampuan menembak pada saat bermain bola basket dan sudah sesuai dengan karakteristik siswa, (c) permainan rintang tali berorientasi pada kebutuhan siswa dan dapat mengeksplorasi kegiatan belajar teknik dasar menembak, (d) permainan mengembangkan kemampuan siswa dalam bekerja sama dan memotivasi siswa dalam berinteraksi dengan siswa yang lain, dan (e) permainan mendorong siswa untuk memecahkan masalah dan mendorong siswa dalam mematuhi peraturan.

\section{Happy Game}

Model permainan happy game untuk pembelajaran teknik dasar bola basket menun- jukkan kategori sangat baik dengan rata-rata 44,5 dan persentase 98,8 \%. Hal-hal yang menyebabkan model permainan happy game dalam kategori sangat baik akan dijelaskan sebagai berikut: (a) permainan happy game mengembangkan kemampuan siswa dalam menembak dan pada saat melakukan permainan siswa diharuskan berpikir, (b) siswa terlihat senang dan aktif ketika melakukan permainan happy game, (c) permainan happy game membekali siswa untuk memiliki kemampuan mengoper, menggiring, dan menembak pada saat bermain bola basket dan sudah sesuai dengan karakteristik siswa, (d) permainan happy game berorientasi pada kebutuhan siswa dan dapat mengeksplorasi kegiatan belajar teknik dasar mengoper, menggiring, dan menembak, dan (e) permainan mengembangkan kemampuan siswa dalam bekerja sama dan memotivasi siswa dalam berinteraksi dengan siswa yang lain.

Dari 9 permainan yang dihasilkan, terdapat 2 permainan yang masuk dalam kategori baik, yaitu permainan kejar mengejar dan tembak tongkat. Permainan kejar mengejar dan permainan tembak tongkat masuk dalam kategori baik karena siswa kurang akif dalam menjalankan permainan. Model permainan untuk pembelajaran bola basket secara keseluruhan dalam kategori sangat baik dengan rata-rata 41,3 dan persentase $91,7 \%$.

Jadi dapat disimpulkan bahwa model permainan untuk pembelajaran teknik dasar bola basket di SMP layak untuk digunakan dan dijadikan pedoman untuk pembelajaran bola basket di SMP.

Hasil nilai pretest untuk shooting sebesar 6,1, dribbling sebesar 18,6, passing sebesar 21. Untuk nilai posttest shooting diperoleh sebesar 6,9, dribbling sebesar 21, passing sebesar 23,5. Pada saat dilakukan tes awal didapat nilai pretest dengan rata-rata nilai adalah 15,2 . Setelah dilaksanakan pembelajaran dengan permainan, rata-rata nilai posttest yang diperoleh peserta didik adalah 17,1. Berarti terjadi peningkatan (gain) sebesar 1,9. Untuk lebih memperjelas hasil uji keefektifan produk berikut ini disajikan histogram yang dapat dilihat pada Gambar 1 . 


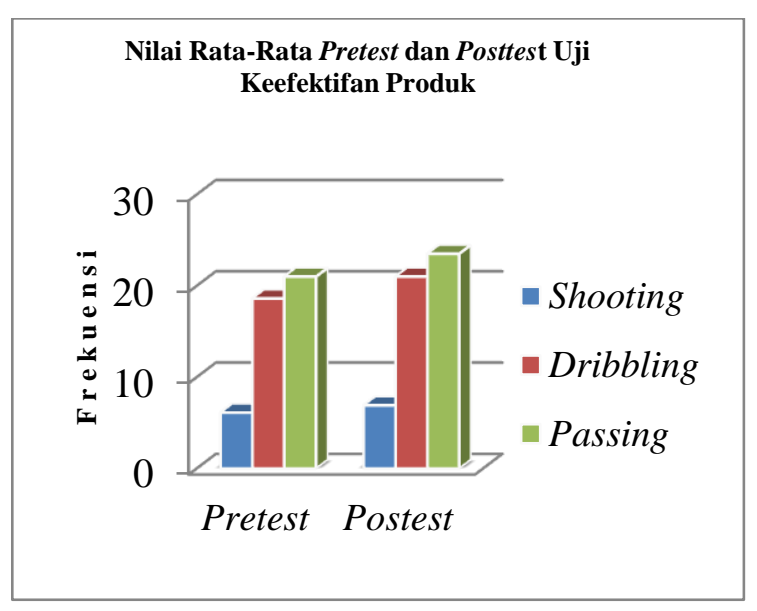

Gambar 1. Histogram Nilai Rata-Rata Pretest dan Posttest Uji Keefektifan Produk

\section{SIMPULAN DAN SARAN}

\section{Simpulan}

Berdasarkan hasil penelitian, dapat diambil suatu kesimpulan yaitu tersusun model permainan untuk pembelajaran teknik dasar bola basket di SMP yang terdiri atas sembilan model permainan. Model permainan tersebut yaitu: (1) lempar nama, (2) lempar target, (3) lempar gerak, (4) fun dribbling, (5) target dribbling, (6) kejar mengejar, (7) tembak tongkat, (8) rintang tali, dan (9) happy game.

Dari hasil model permainan yang dikembangkan, diketahui bahwa model permainan yang disusun sangat sesuai dengan karakteristik serta pertumbuhan dan perkembangan anak SMP yang ditunjukkan oleh hasil observasi antara pakar dan praktisi sehingga model permainan layak digunakan. Hasil penelitian ini menjawab permasalahan yaitu: (1) model permainan teknik dasar passing dapat dilakukan dalam permainan lempar nama, lempar target, dan lempar gerak, (2) model permainan teknik dasar dribbling dapat dilakukan dalam permainan fun dribbling, target dribbling, dan kejar mengejar, (3) model permainan shooting dapat dilakukan dalam permainan tembak tongkat dan rintang tali, (4) proses pembelajaran teknik dasar bola basket terdiri atas tiga aspek yaitu teknik dasar passing, dribbling dan shooting merupakan fondasi utama untuk bermain bola basket. Permainan untuk pembelajaran teknik dasar bola basket mengacu pada prinsip pembelajaran fisik motorik anak SMP, (5) model permainan untuk pembelajaran teknik dasar sesuai dengan pertumbuhan dan perkembangan anak SMP yang ditunjukkan dengan adanya jenis kegiatan yang mengandung unsur pengembangan otot-otot kecil maupun besar, pengembangan kognitif, bahasa, dan emosi, dan (6) model permainan untuk pembelajaran teknik dasar membuat siswa lebih aktif dan senang karena aktivitas jasmani tersebut dapat memfasilitasi dan mengeksplorasi anak terhadap peningkatan teknik dasar dengan kegiatan yang ada di permainan bola basket dengan ditunjukkan adanya kegiatan jasmani mengenai teknik dasar bola basket yaitu passing, dribbling, dan shooting.

Dari uji keefektifan diperoleh hasil model permainan sangat efektif untuk meningkatkan keterampilan teknik dasar bola basket siswa SMP. Produk penelitian pengembangan ini yaitu buku panduan praktis permainan untuk pembelajaran teknik dasar bola basket anak SMP yang berjudul "Permainan Teknik Dasar Bola Basket: Model Permainan untuk Pembelajaran Teknik Dasar Bola Basket di Sekolah Menengah Pertama". Buku panduan praktis permainan untuk pembelajaran bola basket berisi sembilan permainan, yaitu: (1) Lempar Nama, (2) Lempar Target, (3) Lempar Gerak, (4) Fun Dribbling, (5) Target Dribbling, (6) Kejar Mengejar, (7) Tembak Tongkat, (8) Rintang Tali, dan (9) Happy Game.

\section{Saran}

Setelah diketahui keefektifan model permainan peneliti menyarankan hendaknya para guru penjasorkes SMP menggunakan model permainan ini dalam proses pembelajaran penjasorkes khususnya pada saat menyampaikan materi teknik dasar bola basket.

\section{DAFTAR PUSTAKA}

Ahmadi, N. (2007). Permainan bola basket. Surakarta: Era Intermedia.

Bell, B. A. (2014). Pretest-posttest design. In N. J. Salkind (Ed.), Encyclopedia of research design. Thousand Oaks California : SAGE Publications, Inc. http://doi.org/10.4135/9781412961288.n3 31

Chroni, S., Perkos, S., \& Theodorakis, Y. (2007). Function and preferences of motivational and instructional self-talk for adolescent basketball players. Athletic Insight: The Online Journal of Sport Psychology, 9(1), 19-31. Retrieved from http://www.athleticinsight.com/Vol9Iss1/ BasketballPDF.pdf

Dwiyogo, W. D. (2004). Konsep penelitian dan pengembangan. Malang: Pusat Kajian Kebijakan Olahraga LEMLIT UM. 
Gall, M. D., Gall, J. P., \& Borg, W. R. (2007). Educational research: An introduction. Pearson/Allyn \& Bacon.

Kirk, R. E. (2002). Experimental design: Procedures for the behavioral sciences. Waco, Texas: SAGE Publications, Inc. Retrieved from https://uk.sagepub.com/engb/asi/experimental-design/book233742

Mardapi, D. (2012). Pengukuran penilaian dan evaluasi pendidikan. Yogyakarta: Nuha Medika.

Muhajir. (2016). Pendidikan jasmani, olahraga dan kesehatan untuk SMA/MA kelas X.
Bandung: Erlangga.

Oliver, J. A. (2004). Basketball fundamentals. Human Kinetics. Retrieved from https://books.google.co.id/books/about/Ba sketball_Fundamentals.html?id=5R9dGB uuG0MC\&redir_esc $=\mathrm{y}$

Saryono, S. (2011). Prinsip dan aplikasi dalam modifikasi sarana dan prasarana penjas. Jurnal Pendidikan Jasmani Indonesia, 7(1). Retrieved from http://journal.uny.ac.id/index.php/jpji/arti cle/view/481

Sugiyono, S. (2006). Statistika untuk penelitian. Bandung: CV Alfabeta. 